\title{
THE FATHER'S STORYTELLING APPROACH IN IMPROVING CHILDREN'S VOCABULARY USING ANIME
}

\author{
${ }^{\# 1}$ Pramudana Ihsan, ${ }^{* 2}$ Annisa Tiara Syafitri \\ ${ }^{\# 1}$ Pramudana Ihsan, English Education Lecturer, Universitas Muhammadiyah Surabaya, \\ Indonesia \\ ${ }^{* 2}$ Annisa Tiara Syafitri, English Education Student, Universitas Muhammadiyah Surabaya, \\ Indonesia
}

Corresponding Author Email: pramudanaihsan@fkip.um-surabaya.ac.id

\begin{abstract}
A B S T R A C T S
This research is based on the implementation of anime for children's vocabulary mastery by their father's storytelling. The researcher describes the impact of teaching English using vocabulary through anime reading materials using several vocabulary teaching techniques. The subject of this research is a father who works from home and his son who is studying English, amounting to 10 couples. This methodology has several advantages including classroom action research which consists of planning and taking surveys through online data collection. Data were analyzed with qualitative data. After analyzing, the authors concluded that the learning process using cartoons had good results. This can be seen from the increase in children's vocabulary and increased English language skills. The results were particularly good in the child's increased memory and attractiveness to read. The vocabulary of $85 \%$ of children is also increased and $15 \%$ can implement a few words in daily conversation. During the teaching and learning process, almost $90 \%$ of children feel comfortable, active, and excited. Research has shown that teaching using animated cartoons can increase students' vocabulary mastery.
\end{abstract}

\begin{tabular}{l}
\hline A R T I C L E I N F O \\
\hline Article History: \\
Received: May, 2021
\end{tabular}

Revised: May, 2021

Published: June, 2021

Keywords:
Anime,,
Story Telling,
Vocabulary,
Young learner,

\section{Keywords:}

Anime,

Vocabulary,

Young learner,

How to cite: Ihsan, P., \& Syafitri, A. (2021). The Father's Storytelling Approach in Improving Children's Vocabulary Using Anime. Jo-ELT (Journal of English Language Teaching) Fakultas Pendidikan Bahasa \& Seni Prodi Pendidikan Bahasa Inggris IKIP, 8(1), 49-58. doi:https://doi.org/10.33394/jo-elt.v8i1.3790

\section{INTRODUCTION}

In learning English, which includes several skills such as speaking, reading, writing, and listening. In good communication, vocabulary is needed to support the communication process. Learning English at home, especially for children can usually use a lot of media such as books, audiovisuals, or objects around. Things like this can affect English language skills, especially vocabulary mastery and children's memory. Parents can also play a role during the learning process at home. However, children usually have difficulty remembering and feel overwhelmed when asked to memorize new words.

Several studies have used many methods for teaching vocabulary to children. One of them is in research using applications that is Quizlet application (Rizky Setiawan \& Wiedarti, 2020). The results of this study were the vocabulary learning process using the observation checklist. In data processing, the Wilcoxon test was used. The results showed that the use of the Quizlet application was effective in increasing students' motivation to learn vocabulary. Apart from that other applications are used (Dzulfikri, 2016). This study investigates the 
perceptions of students towards Application-Based Crossword Puzzles and how playing this game can affect the development of vocabulary among students. The study findings showed that the participants viewed the game and that it positively affected the players' vocabulary retention as indicated by the results of the tests conducted. English vocabulary plays an important and complex role, not only in learning the first language but also in mastering the second language (Susanto, 2017).

Teaching English, especially to increase vocabulary in children, can be done in different and interesting ways, according to the child's preferences. How to develop good character in children concludes seven ways that children should do to cultivate virtue (good character), empathy, conscience, self-control, respect, kindness, tolerance, and justice (A. Kamaruddin, 2012). So it's not just giving a few words and having them memorize it. This is different from how to teach adults, it needs patience and consistency so that they quickly understand and remember. Children learn according to their mood and interest in what will be learned later. In school maybe they can learn directly with the teacher, but in a pandemic like now, learning is becoming increasingly difficult to understand and children are forced to study with their parents at home where parents who work are also doing work from home. To have a good achievement in mastering English, it is necessary to study it from an early age (Achmad, 2014). Usually the one who teaches children at home is their mother or siblings, it is rare to hear that their father teaches them at home. The existence of comics can be used as a solution to the risk of failure in a learning process (Pratiwi \& Kurniawan, 2013). This is a new thing for the author to research and want to know the impact on children and add vocabulary to develop the potential of English with their father by using anime media by the title "The Father's Story Telling Approach in Improving Children's vocabulary Using Anime".

\section{RESEARCH METHOD}

The limitations of the learning design include solving problems with low vocabulary by collecting data from observations of parents and children who have applied the method. To improve the reliability of measuring instruments, the data were analyzed using descriptive qualitative data. This descriptive analysis is used to determine the level of accuracy, effectiveness, and attractiveness of the product or development results in the form of comics (Rifky, 2017).

\section{Research Design}

This research on teaching media uses comic book media by parents who are expected to produce maximum data or research results. The use of comic media in teaching foreign languages, especially English, is expected to attract children's attention and interest in the learning process to increase vocabulary when compared to the use of ordinary reading text or with books. Comics are in accordance with the current conditions of students with the theme of funny and pictorial topics, so it is hoped that children can acquire and add new words that are generated from learning to use this media. Creativity is a crucial thinking skill to create educational innovation, which is novel, valuable, and useful in education (Seechaliao, 2017).

\section{Population and Sample OR Subject}

The research conducted by the researcher is an innovation of the previous method using different media. Observations were made on 10 parents (fathers) who have children aged 6-12 years and are learning English from home. Spread some questions on google form links that relate to learning using comics and how they feel when studying together. As well as the impact for those who have tried this method. Those who fill in the google form are parents who work from home and teach their children to improve their vocabulary. 


\section{Instruments}

The data obtained from this study is the research applied to parents (fathers) and their children. They use comic anime media and the researchers will see the results after several times they study together. The researchers also recorded the steps taken during the study. The first step is to collect several samples, there are children and parents. To see how their progress during teach children to use comics. Then make questions, share them and analyze the data and findings that have been obtained. The questionnaire posed by the researcher can be seen in table 1 .

Table 1

The Questionnaire of the Research Instrument

\begin{tabular}{|c|l|}
\hline $\begin{array}{c}\text { Number } \\
\text { of } \\
\text { Items }\end{array}$ & \multicolumn{1}{|c|}{ The Questionnaire } \\
\hline 1. & $\begin{array}{l}\text { Usually, teach children to speak English in what way? Have you ever } \\
\text { applied to learn to use comics before to increase children's vocab? }\end{array}$ \\
\hline 2. & What reading material do you use to teach children? \\
\hline 3. & $\begin{array}{l}\text { Is this method of using reading material effective enough to increase } \\
\text { children's vocab? }\end{array}$ \\
\hline 4. & If so, what kind of development did the child show? (Explain) \\
\hline 5. & Are there any difficulties learning to use this method? (specify if any) \\
\hline 6. & $\begin{array}{l}\text { Studying like this is boring or fun? Describe how was your experience } \\
\text { teaching children at first? (Explain) }\end{array}$ \\
\hline 7. & How long does it take for children to remember words? \\
\hline 8. & What words do children remember the most? \\
\hline 9. & Can children make synonyms of the word? (if yes, provide examples) \\
\hline 10. & How do you think about this learning media and method? \\
\hline
\end{tabular}

At this last step, the researchers processed the data. The answers given by parents when filling out the questionnaire will be explained with qualitative data. Most parents think that the method of using anime comic media is very effective and some of them say it is difficult to practice. However, from the results obtained, the researchers found that the use of this method could be implemented in children while studying at home.

From what the parents explained in the questionnaire, their child learns English and masters vocabulary from school to be precise learning from books. During the pandemic, it is certain that children learn from home or online learning with textbooks because parents do not mention other learning methods at home that they do. So mastery of foreign languages is normal for children and is no longer practiced at home. After approximately 14 days of using the comic anime method in children, the child's vocabulary increases, especially in nouns and verbs. The delivery of children's expressions of books read by parents is a very good achievement because it is practiced in daily activities. Researchers can see the results and make conclusions about which learning media is more effective, and see whether there is significance in the results of the research treatment carried out on the object.

\section{Data Analysis}

According to Creswell (2014), qualitative research is an inquiry process of understanding based on distinct methodological traditions of inquiry that explore a social or human problem. The researchers build a complex, holistic picture, analyzes word, report detailed views of information, and conducts the study in a natural setting. In this study, the researcher adopted Cameron, (2003) for indicators in vocabulary, those are; a) Pronunciation, b) Spelling, c) Grammar, d) Meaning 
The use of anime comics or pictorial reading hoped can provide contribution and input to the education system in this country. Comics, known as pictorial reading, is expected to attract and arouse children's interest and motivation at home in learning English. Of course, the material or topic used in the comic strip are dialogues that are appropriate for elementary school children aged 6-12 years and it is recommended to use funny or action reading, such as Sword art online, my heart Saibou, Kaguya-sama, Hotarubi no Morie, Umaru chan, Madouka, and others.

From the many different strategies, there are many options from which learners consciously select in order to optimize their chances of success in achieving their goals in learning and using the language (A. Gani et al., 2015). The research approach is observation research which is arranged into 2 cycles and each cycle consists of four stages, namely planning, action, observation, and reflection. In this method, children will be taught how anime comics can help their speaking skills with their parents. The stages can be seen in table 2.

Table 2

The Stages of Research Observation

\begin{tabular}{|c|c|}
\hline Steps & The Activity \\
\hline Planning & $\begin{array}{l}\text { 1. Preparing the questionnaire } \\
\text { 2. Preparing comic anime recommendations for children. } \\
\text { 3. Preparing the population/object } \\
\text { 4. Preparing observation checklist. }\end{array}$ \\
\hline Action & $\begin{array}{l}\text { 1. Asking respondent to fill in their identity by google form } \\
\text { 2. Sharing questions to the respondent by google form } \\
\text { 3. Sharing anime comic recommendations. }\end{array}$ \\
\hline Analyzing & $\begin{array}{l}\text { 1. In the beginning, children did it well. Good speaking but many } \\
\text { miss pronunciation. The parent helps them to make it correct } \\
\text { 2. Children interest to learn using this method }\end{array}$ \\
\hline Result & $\begin{array}{l}\text { 1. The researcher evaluates the implementation of comic anime } \\
\text { with cooperative learning. } \\
\text { 2. The researcher linking with the hypothesis. } \\
\text { 3. The researcher found the weaknesses during the teaching- } \\
\text { learning process from the comment of parents. } \\
\text { 4. The researcher arranges a reflection for the next cycle }\end{array}$ \\
\hline
\end{tabular}

Parents read stories that have been recommended. There are 2 stories that the researchers gave for parents to try for their children. In a day, parents read 2 different titles to their children. The research conducted on the first day went well and could be conditioned by parents and cooperation with their children. At first, the children were read the story by the parents and asked to imitate some vocabulary in various expressions.

In the second cycle, the researchers did the same thing in a slightly different way. But at this step, the parents read by adding a little new vocabulary to the original sentences in the book so that the child's knowledge increases. At first, the parents read the story by themselves, and in the second stage, they read it together. The result is children more enthusiastic and more questions from children that appear. The examples of anime comics used for children's learning media at home that parents can apply can be seen in figure 1 . 

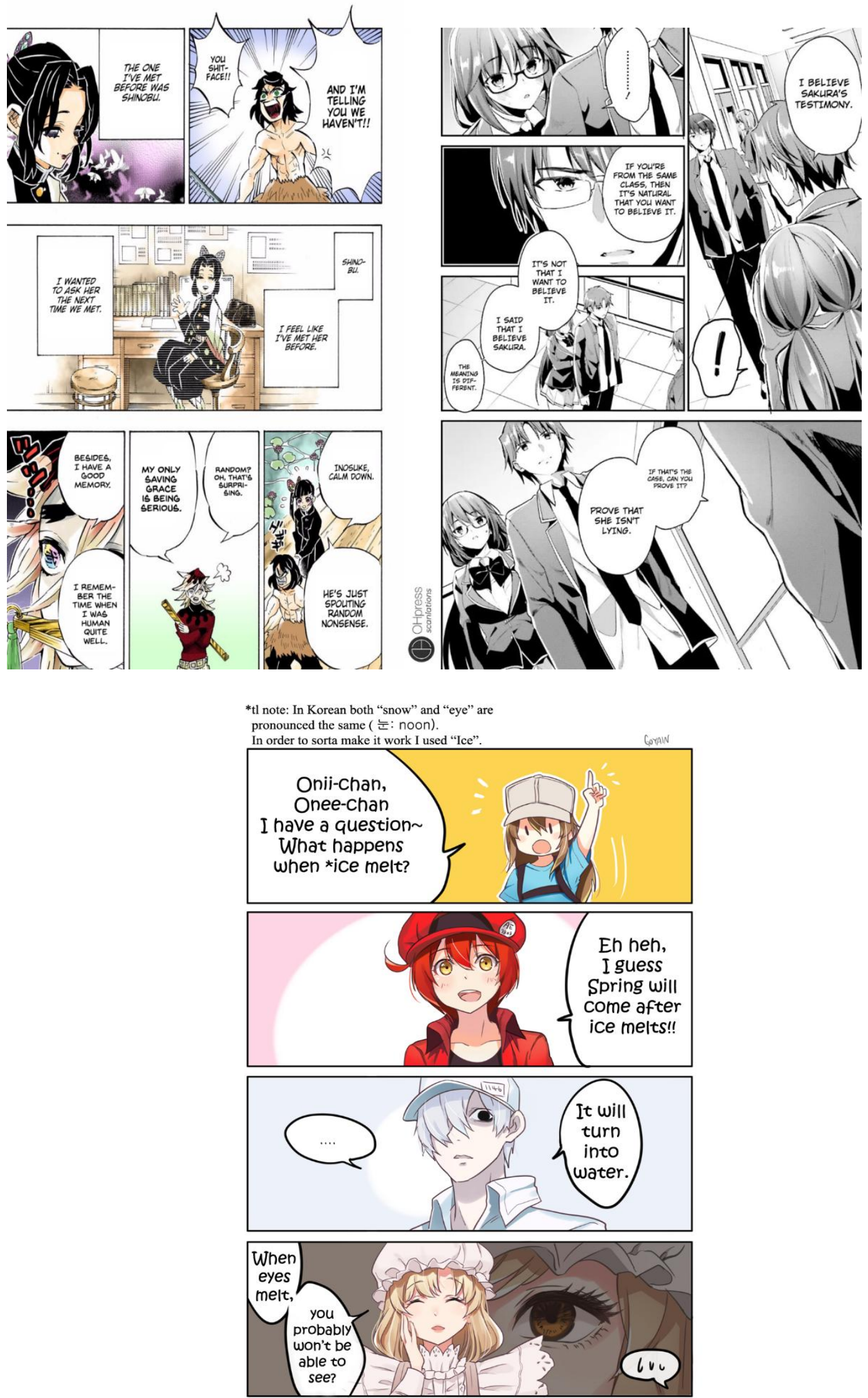

Figure 1. Anime Comics as Learning Media 


\section{RESEARCH FINDINGS AND DISCUSSION Research Findings}

The following data shows that teaching English using comic strip media to parents and children shows better results than using ordinary reading text media.

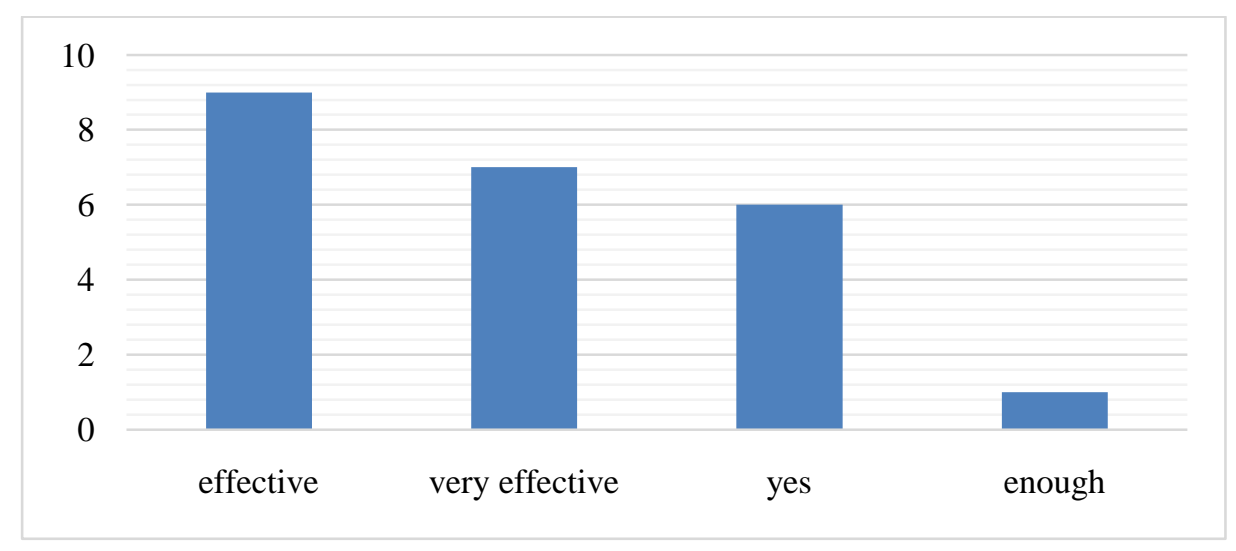

Figure 2. The Effectiveness of the Method

Figure 2 shows that this method is very effective and helps children to improve their vocabulary. The reason parents mostly said that this method can improve English vocabulary and that it is fun to do and define. Parents also enjoy studying with their children because children are also interested in learning them.

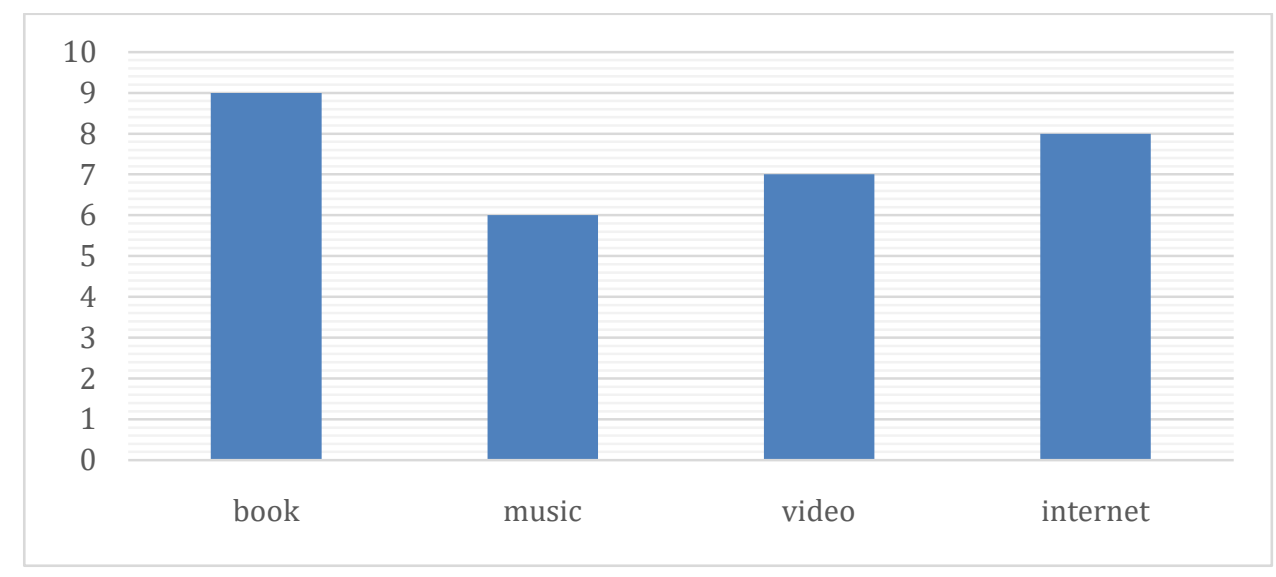

Figure 3. The Way Parents Teach Their Children

Figure 3 shows most parents teach their children before this method is to use ordinary reading book materials and also by internets such as books, online dictionaries, and YouTube. This does not have a good impact on children's memory due to the absence of parental guidance. However, after there was assistance with a different method, the results obtained were more satisfying. 


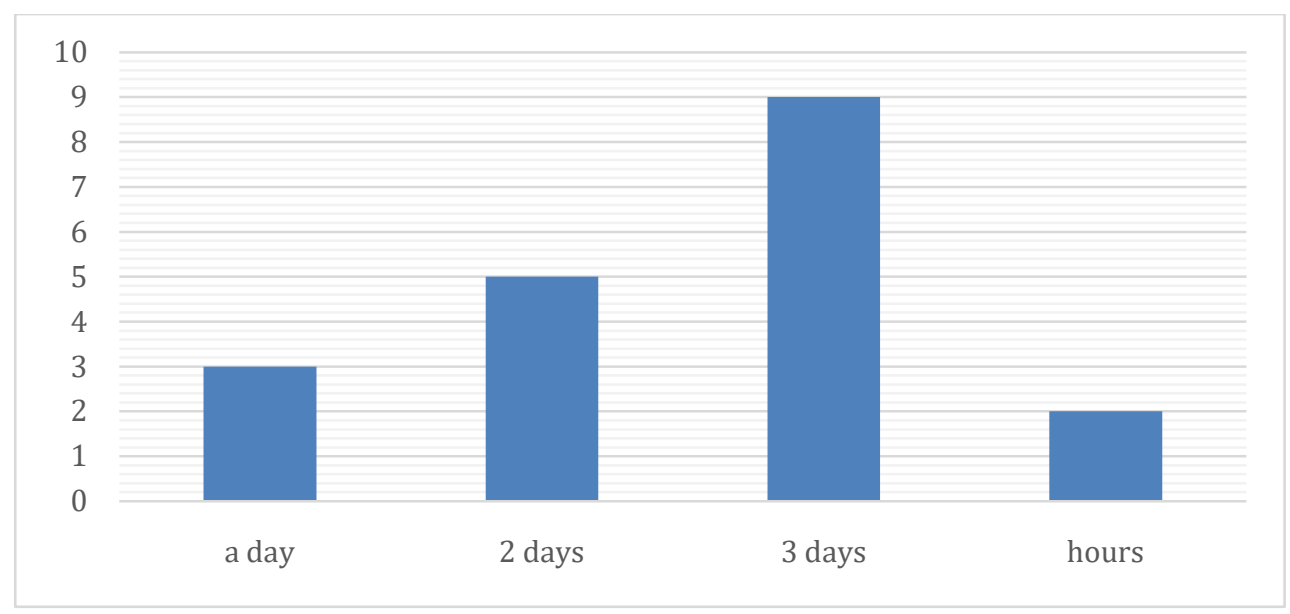

Figure 4. Child Memorize the Word

Figure 4 shows the average time it takes for children to memorize and remember new words is around 2-3 days per word. In less than one week the child can master new words and apply them to everyday conversations. This is evidenced by what is shown in the table. Some even remember it within a few hours. This kind of response is what researchers hope will be one of the best methods for teaching English to children. In addition, the closeness of father and kids is better because they do things together and routinely.

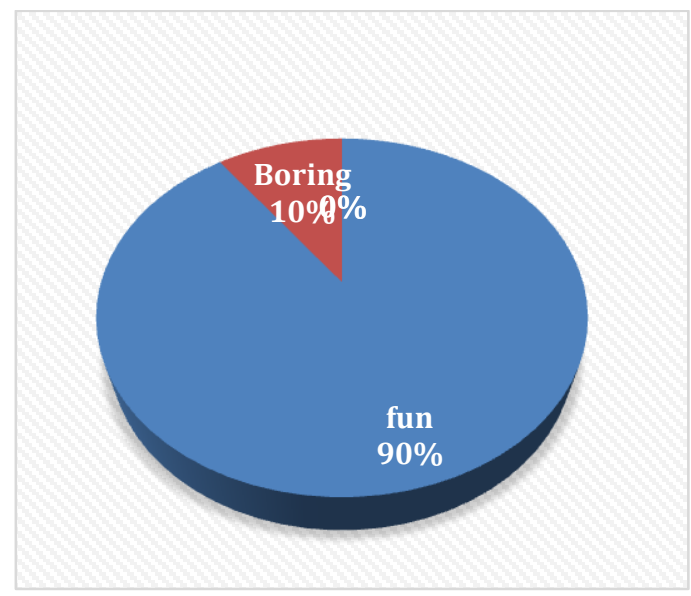

Figure 5. Fun or Boring

Figure 5 shows how much fun it is to learn using this method. Almost all respondents stated that this was very interesting and fun. This is because children prefer media which they find interesting and this comic is one of them. With pictures, not only writing, they can imagine what is going on and imagine the images in the comics. they have an idea of what they read and learn. 


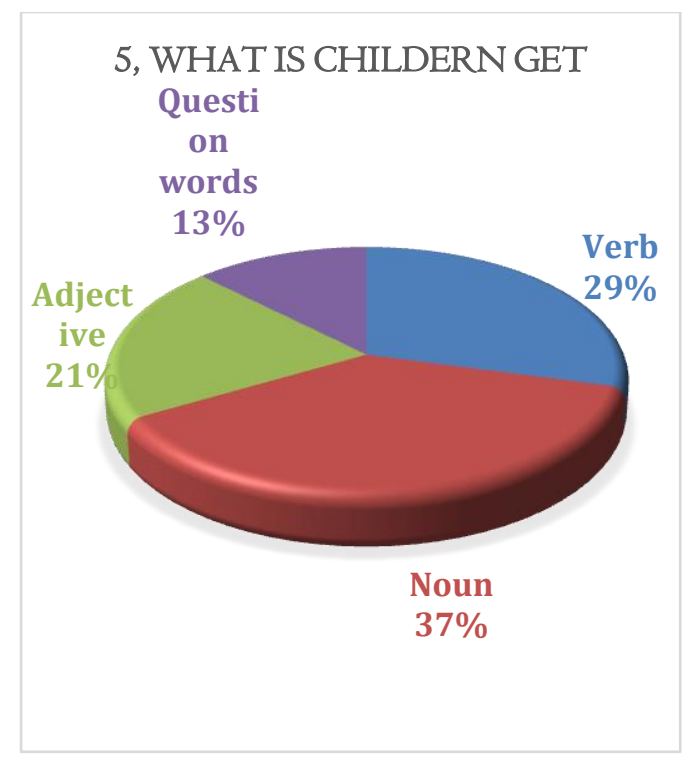

Figure 6. What Children Get

Figure 6 shows the vocabulary they learn, the noun is the vocabulary that is most remembered and understood the most. such as fruit names, names of objects around, etc. Besides that, there are verbs, adjectives, and question words, namely $5 \mathrm{~W}+1 \mathrm{H}$. Many words are remembered by children when learning. The improvement shown by the children tells that this method is good and feasible to be applied.

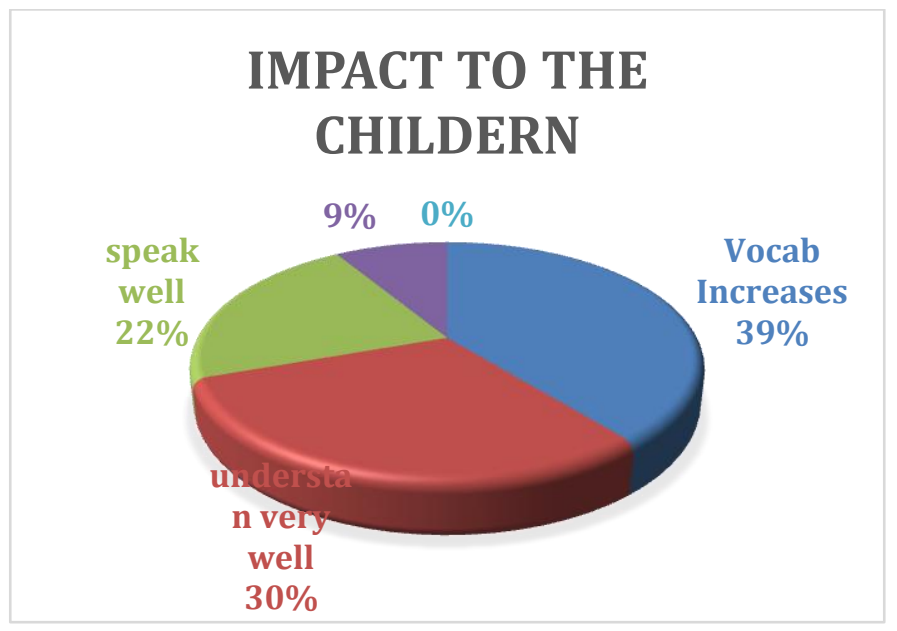

Figure 7. Impact to the Children

Figure 7 shows children after learning vocabulary through anime comics are very good. The highest percentage is that children's vocabulary increases, knowledge increases because children quickly understand. In addition, they are also able to speak and imitate the correct way of reading and use it for daily conversations. Interest in reading in children also increases.

\section{Discussion}

In the learning process and during active growth, children are often difficult to be invited to learn and are less able to absorb knowledge properly without good supervision from parents at home or teachers at school. Building curiosity and enabling children to apply what they have learned from the people around them and their environment requires something more than they know. Such as learning a foreign language which is an important point and a lesson that must be mastered from an early age. Learning with the usual method 
in class without any other support that makes the childer's memory stronger then the results obtained are not optimal.

One of the basic things that can be learned by children and can be monitored by parents at home is learning to increase vocabulary. The importance of breadth for language learners is when they have to understand the meaning when reading a text. Children, who can find useful information for themselves from reading, will sooner or later be interested in reading books related to their field of interest (Herlina, 2016). The number of words they know will affect their reading comprehension ability. Learning at school with a teacher is a good way, but learning with parents at home is read by reading stories using anime comics that make children interested in learning while having fun. Learners sometimes forget the meaning of the words owing to the fact that they have not used an effective technique to learn them (Enayati \& Gilakjani, 2020). The use of tools/media in an effort to improve and enrich students' vocabulary is highly recommended (Charles D. Ffries, 1945:959, 2016).

This research is based on the experiences of the related object. This method is very doable and tried to teach and improve children's vocabulary and English skills from an early age. The success of the use of comics in the world of education has been proven by Japan with the emergence of knowledge comics aka jitsumu manga or lesson comics as a medium to convey certain lessons (Karmiani, 2018). The data that has been shown above and the answers given by the research object is very satisfying, thus convincing the author and readers that the use of comics for learning English to children at home does not disappoint. Like the application of other methods, weaknesses and limitations also exist in this media research. Anime comics are media with written images, so they cannot produce sound and moving images like videos. So it's possible that children can get bored at any time while listening to stories or reading them on their own, but it's different if the comics are colorful and the storyline is interesting. Then the difficulty when asking children to be able to focus because in the learning process they must listen well and not all children can be in silent mode for a long time. While another weakness lies in the parents, not all parents who work at home can apply this method to their children because it is possible that they also do not understand the importance of learning foreign languages and prefer to enroll their children in learning institutions.

Future research can develop this method and media as a reference for teachers so that students do not feel bored with the usual way of learning. Great benefit for exploring the phenomena of vocabulary learning with more respondents, direct observation in class, and student responses to vocabulary learning (Susanto et al., 2020). Maybe this method can be tried for middle school, not only comics but with media that does not contain many written elements such as a collection of short storybooks and then it can be continued by reading a novel. in the pandemic era like now, it would be nice if we read a lot and watch something that can improve academic and non-academic abilities. So, we can all become the next generation who are equipped to compete widely and internationally.

\section{CONCLUSION}

In overcoming the problem of teaching in improving children's language skills, especially at home, parents can use simple things and of course attract children's interest. Language learning at home can be a way to learn as well as have fun for children so that it takes advantage of free time to increase knowledge.

\section{REFERENCES}

A. Gani, S., Fajrina, D., \& Hanifa, R. (2015). Students' Learning Strategies for Developing Speaking Ability. Studies in English Language and Education, 2(1), 16. https://doi.org/10.24815/siele.v2i1.2232. 
A. Kamaruddin, S. (2012). Character Education and Students Social Behavior. Journal of Education $\quad$ Learning (EduLearn), 223. https://doi.org/10.11591/edulearn.v6i4.166.

Achmad, D. (2014). Investigating elementary school pupils' proficiency in mastering English vocabulary. Studies in English Language and Education, 1(1), 1. https://doi.org/10.24815/siele.v1i1.1116.

Cameron, L. (2003). Challenges for ELT from the expansion in teaching children. ELT Journal, 57(2), 105-112. https://doi.org/10.1093/elt/57.2.105.

Charles D. Ffries (1945:959). (2016). K A N D A I ORIENTASI PENELITIAN PENERJEMAHAN MUTAKHIR DI INDONESIA DALAM TESIS DAN DISERTASI (Orientation of the Latest Researches on Translation in Indonesia in Thesis and Disertations). Kandai, 9(2), 262-275.

Creswell, J. W. (2014). Research design, qualitative, quantitative, and mixed methods approach (4th Ed.). United States of America: Sage Publications.

Dzulfikri, D. (2016). Application-Based Crossword Puzzles: Players' Perception and Vocabulary Retention. Studies in English Language and Education, 3(2), 125. https://doi.org/10.24815/siele.v3i2.4960.

Enayati, F., \& Pourhosein Gilakjani, A. (2020). The Impact of Computer Assisted Language Learning (CALL) on Improving Intermediate EFL Learners' Vocabulary Learning. International Journal of Language Education, 4(2), 96-112. https://doi.org/10.26858/ijole.v4i2.10560.

Herlina, H. (2016). The Effect of Interest in Reading on Mastery of English Vocabulary with Fifth Grade Elementary Students. Studies in English Language and Education, 3(2), 192. https://doi.org/10.24815/siele.v3i2.4965.

Karmiani, S. (2018). Penggunaan Media Komik Berbahasa Inggris Sebagai Upaya Meningkatkan Kemampuan Membaca Pemahaman Bahasa Inggris Pada Siswa Kelas Viii Smpn 3 Teluk Kuantan. JURNAL PAJAR (Pendidikan Dan Pengajaran), 2(6), 883. https://doi.org/10.33578/pjr.v2i6.6514.

PRATIWI, W., \& Kurniawan, R. (2013). Penerapan Media Komik Sebagai Media Pembelajaran Ekonomi Di Sma Negeri 3 Ponorogo. Jurnal Pendidikan Ekonomi (JUPE), 1(3), 1-16.

Rifky, H. \&. (2017). Pengembangan media pembelajaran berbasis komik pada mata pelajaran ilmu pengetahuan sosial kelas IV MI Nurul Hidayah Roworejo Negerikaton Pesawaran. Jurnal Pendidikan Dan Pembelajaran Dasar, 4(1), 34-46.

Rizky Setiawan, M., \& Wiedarti, P. (2020). The effectiveness of quizlet application towards students' motivation in learning vocabulary. Studies in English Language and Education, 7(1), 83-95. https://doi.org/10.24815/siele.v7i1.15359.

Seechaliao, T. (2017). Instructional Strategies to Support Creativity and Innovation in Education. Journal of Education and Learning, 6(4), 201. https://doi.org/10.5539/jel.v6n4p201.

Susanto, A. (2017). Assessing the relationship between Vocabulary Level Test (VLT) and reading comprehension. Studies in English Language and Education, 4(2), 157. https://doi.org/10.24815/siele.v4i2.5118. 